\title{
SYSTEMIC ANTIBIOTICS IN ENDODONTIC PRACTICE: MANDATORY OR, OPTIONAL
}

\author{
${ }^{1}$ Dr.Maneesha Das, ${ }^{2}$ Dr.Bharat Deosarkar, ${ }^{3}$ Dr.Renu S Pande, ${ }^{4 *}$ Dr.Abhishek Singh Nayyar \\ ${ }^{1}$ Senior Lecturer, Department of Conservative Dentistry and Endodontics, Saraswati-Dhanwantari Dental \\ College and Hospital and Post-Graduate Research Institute, Parbhani, Maharashtra, India \\ ${ }^{2}$ Senior Lecturer, Department of Conservative Dentistry and Endodontics, Saraswati-Dhanwantari Dental \\ College and Hospital and Post-Graduate Research Institute, Parbhani, Maharashtra, India \\ ${ }^{3}$ Reader, Department of Microbiology, Saraswati-Dhanwantari Dental College and Hospital and Post- \\ Graduate Research Institute, Parbhani, Maharashtra, India \\ ${ }^{4}$ Reader and PG Guide, Department of Oral Medicine and Radiology, Saraswati-Dhanwantari Dental College \\ and Hospital and Post-Graduate Research Institute, Parbhani, Maharashtra, India
}

\begin{abstract}
Antibiotics are life-saving adjuncts to the armamentarium available to health professionals for management of a plethora of infections. In endodontic treatment and trauma cases, antibiotics are prescribed systemically in the form of either oral and/or, parenteral drugs. Systemic antibiotics are routinely used during treatment of acute and chronic odontogenic infections, oral non-odontogenic infections, as prophylactic treatment against focal infections and infections spreading to the neighbouring tissues and organs. In endodontics, systemic antibiotics have a special role since complete eradication of infection from the root canal is difficult owing to the complex anatomy of the root canals and also, in cases of infections extending into the peri-apical region which eventually result in endodontic flare-ups and failure of endodontic treatment. Antibiotics are, also, commonly given as a life saving drugs in immuno-compromised patients with obvious clinical advantages, in patients suffering with infective endocarditis, septicaemia, pyemia, diabetes mellitus and also, in patients receiving radio-chemo-therapies and patients having prosthetic heart valves. This review comprehensively discusses the role of systemic antibiotics in treatment of endodontic emergencies and promoting healing of the peri-apical infections.
\end{abstract}

Key Words: Antibiotics, infections, odontogenic, diabetes mellitus, endodontic flare-ups and failure, bacteremia

\section{INTRODUCTION}

Micro-organisms and their by-products are the main etiologic factors causing progression and persistence of infection in the root canal and the surrounding peri-apical tissues. Elimination of these micro-organisms from the complex inaccessible anatomy of the root canal system is often difficult by mechanical instrumentation alone. This commonly causes re-infection of the root canal and failure of the endodontic treatment. Hence, systemic antibiotics are needed to be prescribed in adult and pediatric patients in various conditions including acute and chronic odontogenic infections as prophylactic measure to control bacteremia and chances of reinfection. ${ }^{1,2}$ Endodontic infections are largely poly-microbial and mixed in nature with predominance of anaerobic bacteria found in all the infections

*Corresponding author:

Email: singhabhishekndls@gmail.com

http://dx.doi.org/10.20530/IJTA $34 \quad 23-27$

ISSN 2320-138X @ 2016 related to oral cavity. In cases of acute infections, systemic antibiotics have proven to be effective in controlling bacteremia and preventing further complications such as fever and malaise. In chronic lesions involving the peri-apical region, the triad of root canal instrumentation along with intra-canal medication and administration of systemic antibiotics are highly effective in giving success to the prognosis of the endodontic treatment procedure. Hence, systemic antibiotics are prescribed as an adjunctive treatment of odontogenic infections. ${ }^{3-5}$

\section{HISTORY}

Antibiotics were first discovered in the year 1928 but were clinically used first during the Second World War (Abott, 2000). Antibiotics became popular since there was rapid recovery of wounded military personnel during the war. The first use of antibiotics in endodontics was introduced in the year 1951 by Grossman as a poly-antibiotic paste known as PBSC (Mixture of penicillin, bacitracin, streptomycin and caprylate sodium) with penicillin being effective against the gram positive organisms, bacitracin against the 
penicillin resistant strains, streptomycin against the gram negative organisms and caprylate sodium against yeasts. Later, caprylate sodium was replaced by nystatin as an important anti-fungal agent. $^{3,6,7}$ Flare-ups in endodontics are caused by various factors such as microbial factors (including gram negative anaerobic micro-organisms namely Bacteroides melaninogenicus), changes in periapical tissue pressure, cell mediators like histamine, serotonin, prostaglandins and leukotrienes, plasma factors including Hageman factor, immunoglobulins like IgG, IgM and IgA and psychological factors with fear, anxiety and previous experiences further worsening the situation and the patient's response to infections as well as treatment. ${ }^{8,9}$ Antibiotics have, also, been used during regenerative procedures for disinfection of the root canal. The most commonly used antibiotic is Triple Antibiotic Paste containing metronidazole, ciplofloxacin and minocycline in the ratio $1: 1: 1$. $^{10}$

\section{Role of Systemic Antibiotics in Odontogenic} Infections:
Systemic antibiotics are routinely administered in acute odontogenic infections including acute dento-alveolar abscesses where there is diffuse spreading infection and systemic manifestations. Biomechanical preparation alone is often insufficient to eradicate the infection from the root canal space and the surrounding tissues. Also, in medically compromised patients, the hostdefence mechanisms are thought to be inadequate and in patients receiving medications like corticosteroids and anti-metabolites or, in cases of systemic diseases like leukemia, HIV, neutropenia, splenectomy, lupus erythematosus, poorly controlled diabetes mellitus and organ transplants patients. $^{11-13}$ Hence, in such conditions, therapeutic dosages of systemic antibiotics becomes mandatory. Systemic antibiotics are, also, indicated in patients with cardiac problems associated with endocarditis following dental treatments. Bacteremia can occur following invasive dental treatment procedures giving rise to shunt and/or, vascular catheter colonization which requires immediate attention by prescription of systemic antibiotics. ${ }^{14-16}$ These have, also, been proven to reduce post-operative pain and swelling

The common prophylactic antibiotic regimens are as follows: ${ }^{7}$

\begin{tabular}{|c|c|c|}
\hline $\begin{array}{l}\text { Medical status and endodontic } \\
\text { procedure }\end{array}$ & No penicillin allergy & In case of penicillin allergy \\
\hline $\begin{array}{l}\text { Healthy (1) Re-implantation of } \\
\text { avulsed teeth }\end{array}$ & $\begin{array}{l}\text { 1) } 1 \mathrm{gm} \text { cephradine orally, } 1- \\
\text { 1.5hr pre-operatively }\end{array}$ & $\begin{array}{l}\text { (1) } 600 \mathrm{mg} \text { Clindamycin }{ }^{\mathrm{a}} \text { orally } \\
\text { 1hr pre-operatively }\end{array}$ \\
\hline $\begin{array}{l}\text { 2) Endodontic surgeries (if } \\
\text { prophylaxis indicated) }\end{array}$ & $\begin{array}{l}\text { 2) } 3 g m \text { amoxicillin orally, } 1 \mathrm{hr} \\
\text { pre-operatively }\end{array}$ & $\begin{array}{l}\text { (2) } 600 \mathrm{mg} \text { Clindamycin }{ }^{\mathrm{a}} \text { orally } \\
\text { 1hr pre-operatively }\end{array}$ \\
\hline $\begin{array}{l}\text { Endocardial disease: } \\
\text { Determination of root canal } \\
\text { length, apicectomy, root } \\
\text { resection, repair of root } \\
\text { perforation, root planing, } \\
\text { extractions, biopsy, incision and } \\
\text { drainage, re-implantation of } \\
\text { avulsed teeth, re-positioning of } \\
\text { displaced teeth }\end{array}$ & $\begin{array}{l}\text { 3gm amoxicillin orally, } 1 \mathrm{hr} \text { pre- } \\
\text { operatively } \\
\text { If special risk, follow BSAC } \\
\text { recommendations. }\end{array}$ & $\begin{array}{l}\text { If special risk }{ }^{\mathrm{b}} \text {, follow BSAC } \\
\text { recommendations. }\end{array}$ \\
\hline $\begin{array}{l}\text { Immuno-compromised: } \\
\text { Chemoprophylaxis is only } \\
\text { required for exodontias, root } \\
\text { planing and endodontic surgeries }\end{array}$ & $\begin{array}{l}\text { 3gm amoxicillin orally, } 1 \mathrm{hr} \text { pre- } \\
\text { operatively } \\
\begin{array}{l}600 \mathrm{mg} \text { Clindamycin } \\
\text { pre-operatively }\end{array}\end{array}$ & \\
\hline $\begin{array}{l}\text { Artificial joint replacement cases: } \\
\text { Chemoprophylaxis is only } \\
\text { required for exodontias, root } \\
\text { planing and endodontic surgeries }\end{array}$ & $\begin{array}{l}\text { 1gm cephradine orally, } 1-1.5 \mathrm{hr} \\
\text { pre-operatively }\end{array}$ & $\begin{array}{l}600 \mathrm{mg} \text { Clindamycin }{ }^{\mathrm{a}} \text { orally } 1 \mathrm{hr} \\
\text { pre-operatively }\end{array}$ \\
\hline $\begin{array}{l}\text { Susceptible to } \\
\text { osteoradionecrosis: Exodontias } \\
\text { and endodontic surgeries }\end{array}$ & $\begin{array}{l}1 \mathrm{gm} \text { cephradine and } 200 \mathrm{mg} \\
\text { metronidazole orally, } 1-1.5 \mathrm{hr} \\
\text { pre-operatively and } 200 \mathrm{mg} \\
\text { metronidazole orally, post- } \\
\text { operatively three times a day for } \\
3 \text { consecutive days }\end{array}$ & $\begin{array}{l}600 \mathrm{mg} \text { Clindamycin }{ }^{\text {a }} \text { orally } 1 \mathrm{hr} \\
\text { pre-operatively and } 200 \mathrm{mg} \\
\text { metronidazole orally, post- } \\
\text { operatively three times a day for } \\
3 \text { consecutive days }\end{array}$ \\
\hline
\end{tabular}


seen during flare-ups following biomechanical preparation of the root canal during endodontic treatment. Anecdotal evidence, also, suggests that administration of systemic antibiotics should be done along with repeated inter-appointment change of intra-canal medicament dressings since pus continues to remain in the complex root canal system. Furthermore, systemic antibiotics should be mandatorily prescribed after single visit endodontics to prevent flare-ups. Systemic antibiotics such as tetracycline or, metronidazole have been found useful in treating periodontal infections and can, also, be used as an adjunct to invasive root planing procedures. Triple antibiotic paste consisting of ciprofloxacin, metronidazole and minocycline in the ratio $1: 1: 1$ has been effective in disinfection of traumatized immature teeth during re-vascularisation procedures. ${ }^{17-21}$

a Patients who have been given Clindamycin must be advised to consult their doctor if diarrhoea develops. Clindamycin tablets should be swallowed with a glass of water to prevent oesophageal irritation.

${ }^{b}$ Special risk patients. The British Society of Anti-microbial Chemotherapy (BSAC) has recognised a group of patients with endocardial disease who they consider as "special risk", particularly, susceptible to infective endocarditis (IE). Special risk patients are classified as those patients with endocardial disease who: (i) have had IE before or; (ii) require a general anaesthetic and/or, (a) have a prosthetic heart valve or; (b) are allergic to penicillin or, have had penicillin more than once in the previous month. Such "special risk" patients are normally considered for medical supervision for dental treatments requiring prophylaxis.

\section{DISCUSSION}

Disinfection of the root canal system plays a pivotal role in the success of endodontic treatment and in promoting the healing of the peri-apical tissues. It primarily involves cleaning and shaping of the canal spaces with appropriate endodontic instruments, proper irrigation to dissolve the necrotic pulpal remnants and to flush-out the debris and the toxins present in them and placement of appropriate inert substitutes and medicaments. Prescription of systemic antibiotics should always be done as an adjunct to appropriate clinical treatment. ${ }^{3-6}$ Systemic antibiotics are recommended especially in cases of acute and chronic odontogenic infections and in patients with specific systemic involvement and with special risk of developing bacteremia. In cases of systemic involvement like fever, malaise, toxaemia, in patients with progressive infections, endocarditis and in patients with immunocompromised status, systemic antibiotics are particularly useful for a faster recovery of the patients. In cases with complicated and/or, disseminated odontogenic infections with systemic complications such as fever, malaise and lymphadenopathy, cellulitis, trismus, in cases of progressive diffuse swelling and bacteremia in immuno-compromised patients, empirical therapy with systemic antibiotics becomes mandatory along with appropriate surgical options. ${ }^{14-17}$ Endodontic infections are usually poly-microbial in nature. Selection of an antibiotic regimen should be based on the knowledge of the efficacy of a particular antibiotic for the bacteria most often associated with severe infections. The most commonly associated micro-organisms in endodontic infections include obligate anaerobes, bacteroides, fusobacterium, peptostreptococcus, actinomyces, eubacterium and propionibacterium. Endodontic infections serve as biological ecosystems where the by-products of one species of bacteria serve as nutrients for another species. The choice of a particular antibiotic is based on the culture and sensitivity testing. ${ }^{23-25}$ Various systemic antibiotics used to treat odontogenic infections

Antibiotic prophylaxis against bacterial endocarditis in oral procedures (AHA): ${ }^{22}$

\begin{tabular}{|c|c|c|c|}
\hline Antibiotic & Indication & Dose & Timing \\
\hline Amoxicillin & Standard & $2 \mathrm{~g} \mathrm{po}, * 50 \mathrm{mg} / \mathrm{kg}$ po & 1 hour before \\
\hline Ampicillin & If oral route cannot be used & $2 \mathrm{~g}$ im or, iv, $* 50 \mathrm{mg}$ im or, iv & $1 / 2$ hour before \\
\hline Clindamycin & $\begin{array}{l}\text { Allergy to penicillin Allergy } \\
\text { to penicillin and if oral route } \\
\text { cannot be used }\end{array}$ & $\begin{array}{l}600 \mathrm{mg} \mathrm{po}, * 20 \mathrm{mg} / \mathrm{kg} 600 \mathrm{mg} \text { po } \\
\text { or, iv, } * 20 \mathrm{mg} / \mathrm{kg} \text { iv }\end{array}$ & $\begin{array}{l}1 \text { hour before } \\
1 / 2 \text { hour before }\end{array}$ \\
\hline $\begin{array}{l}\text { Cephalexin or, } \\
\text { Cefadroxil }\end{array}$ & Allergy to penicillin & $2 \mathrm{~g} \mathrm{po}, * 50 \mathrm{mg} / \mathrm{kg}$ po & 1 hour before \\
\hline $\begin{array}{l}\text { Azithromycin or, } \\
\text { Clarithromycin }\end{array}$ & Allergy to penicillin & $500 \mathrm{mg}$ po, $* 15 \mathrm{mg} / \mathrm{kg}$ po & 1 hour before \\
\hline Cefazolin & $\begin{array}{l}\text { Allergy to penicillin and if } \\
\text { oral route cannot be used }\end{array}$ & $1 \mathrm{~g} \mathrm{im} \mathrm{or,} \mathrm{iv,} * 25 \mathrm{mg} / \mathrm{kg}$ & $1 / 2$ hour before \\
\hline
\end{tabular}


include penicillin, clindamycin, erythromycin, cefadroxil, metronidazole and tetracyclines. Penicillin $\mathrm{V}$ has remained the gold standard antibiotic since its advent as it is effective against various facultative and strict anaerobes found in endodontic infections and is low in toxicity. In cases of unresolved infections and in immunocompromised patients, amoxicillin plus clavulanic acid having higher anti-bacterial effectiveness is recommended. ${ }^{21}$ Metronidazole is given in combination with penicillin to control the anaerobic bacterial spectrums. Clindamycin is recommended in cases of serious odontogenic infections including $\beta$-lactamase producing microorganisms where penicillin has failed and/or, is contraindicated due to penicillin allergy. Erythromycin is, also, indicated in cases with patients allergic to penicillin therapy. Clarithromycin and Azithromycin are the newer generation macrolides used as an alternative to erythromycin since they are effective against facultative and anaerobic bacteria resistant to erythromycin. Cefadroxil is another adjunct used along with other antibiotics to provide a broad spectrum of antibacterial action. Tetracyclines, in vogue, in the past, have limited utility these days since they have been largely replaced with better and more effective antibiotics and because of their associated adverse effects which make them especially restricted in their usage in pregnant and/or, nursing females and children under 8 years of age. 2,26

\section{CONCLUSION}

To conclude, antibiotics are life-saving adjuncts to the armamentarium available to health professionals for management of a plethora of infections. Their appropriate use in specific situations especially in patients who are immunocompromised and at risk of developing bacteremia, systemic antibiotics serve a highly useful role in preventing the further dissemination of infections and risk of developing complications. Their use, however, requires an adequate knowledge of the clinician, evaluation of medical history of the patients and appropriate culture and sensitivity tests indicated in cases with flare-ups and failures and in cases which are resistant to conventional therapeutic options and become recalcitrant to routine treatments.

\section{REFERENCES}

1. Pallasch TJ. Antibiotics in endodontics. Dental Clinics of North America 1979;23:737-46.

2. Longman LP, Martin MV. The use of antibiotics in the prevention of post-operative infection: a re- appraisal. British Dental. 1991 Apr 6;170(7):257-62. Available from: http://dx.doi.org/10.1038/sj.bdj.4807487.

3. Abbott PV, Hume WR, Pearman JW. Antibiotics and endodontics. Australian Dental Journal. 1990 Feb;35(1):50-60. Available from: http://dx.doi.org/10.1111/j.18347819.1990.tb03028.x.

4. Gluskin AH, Cohen AS, Brown DC. Orofacial dental pain emergencies: endodontic diagnosis and management. In: Cohen S, Burns RC, editors. Pathways of the pulp, 7th ed.. St. Louis, MO: Mosby, 1998. p. 20-49.

5. Trope M. Relationship of intracanal medicaments to endodontic flare-ups. Dental Traumatology. 1990 Oct;6(5):226-9. Available from: http://dx.doi.org/10.1111/j.16009657.1990.tb00423.x.

6. Abbott PV. Selective And Intelligent Use Of Antibiotics In Endodontics. Australian Endodontic Journal. 2000 Apr;26(1):30-9. Available from: http://dx.doi.org/10.1111/j.17474477.2000.tb00149.x.

7. Longman LP, Preston AJ, Martin MV, Wilson NHF. Endodontics in the adult patient: the role of antibiotics. Journal of Dentistry. 2000 Nov;28(8):539-48. Available from: http://dx.doi.org/10.1016/s0300-5712(00)00048-8.

8. Morse DR, Furst ML, Belott RM, Lefkowitz RD, Spritzer IB, Sideman BH. Infectious flare-ups and serious sequelae following endodontic treatment: $\mathrm{A}$ prospective randomized trial on efficacy of antibiotic prophylaxis in cases of asymptomatic pulpal-periapical lesions. Oral Surgery, Oral Medicine, Oral Pathology. 1987 Jul;64(1):96-109. Available from: http://dx.doi.org/10.1016/00304220(87)90123-x.

9. Walton R, Fouad A. Endodontic interappointment flare-Ups: A prospective study of incidence and related factors. Journal of Endodontics. 1992 Apr;18(4):172-7. Available from: http://dx.doi.org/10.1016/s0099-2399(06)81413-5.

10. Windleyiii W, Teixeira F, Levin L, Sigurdsson A, Trope M. Disinfection of Immature Teeth with a Triple Antibiotic Paste. Journal of Endodontics. 2005 Jun;31(6):439-43. Available from: http://dx.doi.org/10.1097/01.don.0000148143.802 83.ea.

11. Pallasch TJ, Slots J. Antibiotic prophylaxis and the medically compromised patient. Periodontology 2000. 1996 Feb;10(1):107-38. Available from: http://dx.doi.org/10.1111/j.16000757.1996.tb00071.x.

12. Swift JQ, Gulden WS. Antibiotic therapy-managing odontogenic infections. Dental Clinics of North America. 2002 Oct;46(4):623-33. Available from: http://dx.doi.org/10.1016/s0011-8532(02)00031-9. 
13. Bender IB, Montgomery S. Nonsurgical endodontic procedures for the patient at risk for infective endocarditis and other systemic disorders. Journal of Endodontics. 1986 Jan;12(9):400-7. Available from: http://dx.doi.org/10.1016/s00992399(86)80074-7.

14. Kalkwarf KL, Hinrichs JE, Shaw DH. Management of the dental patient receiving corticosteroid medications. Oral Surgery, Oral Medicine, Oral Pathology. 1982 Oct;54(4):396-400. Available from: http://dx.doi.org/10.1016/0030-4220(82)90385-1.

15. Debelian GJ, Olsen I, Tronstad L. Bacteremia in conjunction with endodontic therapy. Dental Traumatology. 1995 Jun;11(3):142-9. Available from: $\quad$ http://dx.doi.org/10.1111/j.16009657.1995.tb00476.x.

16. Bender IB, Barkan MJ. Dental bacteraemia and its relationship to bacterial endocarditis: preventive measures. Compendium of Continuing Education in Dentistry 1989;10:472-82.

17. Pallasch TJ. A critical appraisal of antibiotic prophylaxis. International Dental Journal 1989;39:183-96.

18. Rimmer A. Intracanal medications and antibiotics in the control of interappointment flare-ups. Quintessence International 1991;22:997-1005.

19. Herrera D, Sanz M, Jepsen S, Needleman I, Roldan S. A systematic review on the effect of systemic antimicrobials as an adjunct to scaling and root planing in periodontitis patients. Journal of Clinical Periodontology. 2002 Dec;29(s3):136-59. Available from: http://dx.doi.org/10.1034/j.1600051x.29.s3.8.x.

20. Gill $Y$, Scully C. Orofacial odontogenic infections: Review of microbiology and current treatment. Oral Surgery, Oral Medicine, Oral Pathology. 1990 Aug;70(2):155-8. Available from: http://dx.doi.org/10.1016/0030-4220(90)90109-6.

21. Pickenpaugh L, Reader A, Beck M, Meyers W, Peterson L. Effect of Prophylactic Amoxicillin on Endodontic Flare-Up in Asymptomatic, Necrotic Teeth. Journal of Endodontics. 2001 Jan;27(1):53-6. Available from: http://dx.doi.org/10.1097/00004770-20010100000019

22. Poveda-Roda R, Bagán JV, Sanchis-Bielsa JM, Carbonell-Pastor E. Antibiotic use in dental practice. A review. Med Oral Patol Oral Cir. Bucal 2007;12:E186-92.

23. Newman MG, van Winkelhoff AJ.Antibiotic and Antimicrobial Use in Dental Practice. 2nd ed. Carol Stream, IL: Quintessence Publishing Co Inc.; 2001.

24. Baumgartner J, Xia T. Antibiotic Susceptibility of Bacteria Associated with Endodontic Abscesses. Journal of Endodontics. 2003 Jan;29(1):44-7. Available http://dx.doi.org/10.1097/00004770-20030100000012.

25. Kuriyama T, Karasawa T, Nakagawa K, Saiki $\mathrm{Y}$, Yamamoto E, Nakamura S. Bacteriologic features and antimicrobial susceptibility in isolates from orofacial odontogenic infections. Oral Surgery, Oral Medicine, Oral Pathology, Oral Radiology, and Endodontology. $2000 \mathrm{Nov}$;00(5):600-8. Available from: http://dx.doi.org/10.1067/moe.2000.109639

26. Baker $K \quad A$, Fotos $P \quad G$. Themanagement of odontogenic infections. A rationale for appropriate chemotherapy. Dent Clin North Am 1994; 38: 689-706. 